\title{
Genetic relationship among indigenous sheep population of Bangladesh
}

\author{
Deb GK ${ }^{1 *}$, MP Choudhury ${ }^{1}$,MA Kabir ${ }^{1}$, MYA Khan ${ }^{1}$, M Ershaduzzaman ${ }^{1}$, TN Nahar ${ }^{1}$, SMJ \\ Hossain ${ }^{1}$, MS Alam ${ }^{1}$ and MA Alim ${ }^{2}$ \\ ${ }^{1}$ Bangladesh Livestock Research Institute, Savar, Dhaka; ${ }^{2}$ National Institute of Biotechnology, Savar, Dhaka
}

\begin{abstract}
The study was conducted to investigate the genetic relationships among indigenous sheep population of Bangladesh (Barind, Jamuna river basin, Coastal and Garole sheep) using microsatellite markers. A total of 96 blood samples were collected from adult sheep of Barind (24), Jamuna River Basin (24), Coastal (24), Garole(10) and available Chotanagpuri (10) sheep. Chotanagpuri sheep was used as an outgroup population. DNA was extracted from blood samples using QIAGEN DNA Mini extraction kit and was quantified using a nanodrop. FAO recommended 13 labeled microsatellite markers were used for polymerase chain reaction (PCR). PCR product was confirmed by $2 \%$ agarose gel electrophoresis and visualized by staining with ethidium bromide.The exact allele sizes in each primer were determined by GeneMaker V1.85 demo. Microsatellite tool kit and Dispan software package were used for calculation of allele frequency, number of alleles per locus, observed and expected heterozygosity and genetic distances $\left(D_{A}\right)$. The Dispan software was used to calculate inter-individual genetic distances. These distance values were used to construct an UPGMA tree. Results showed that average number of polymorphic alleles per locus varied from4 in HUJ616 to 12 in MAF70. Observed heterozygosity was also varied from $0.54 \pm 0.04$ in Coastal to $0.63 \pm 0.03$ in Barind sheep population. Genetic distance between Jamuna river basin and Barind was lowest (0.01) and between Garole and Costal was highest (0.17). Garoleand Chotonagpuri sheep has higher genetic distance from other three sheep populations. Phylogenetic dendogram showed that sheep of Jamuna river basin and barind were belonged to same genetic group. Whereas, coastal, garole and Nagpur sheeps were shown higher genetic distances from Jamuna river basin and coastal sheep. Considering findings of this study it may be concluded that the Barind and Jamuna river basin sheep belongs to a similar genetic group while, Garole and Coastal sheep are belonging to two distinct genetic groups.
\end{abstract}

Keywords: Dendogram, genetic distances, heterozygosity, indigenous sheep

Bangladesh Animal Husbandry Association. All rights reserved.

Bang. J. Anim. Sci. 2019. 48 (1):17-22

\section{Introduction}

Sheep is a promising source of meat and wool of Bangladesh. Bangladesh possesses 3.40 million sheep and most of them are indigenous type (Siddiky, 2018; Hassan and Talukder, 2011). They are sparsely distributed throughout country with a comparatively higher concentration in coastal regions, barind tracts, north-eastern wetlands, sundarban-delta regions and Jamuna river basin areas (Pervage et al., 2009). Few exotic and crossbreds with indigenous sheep are found elsewhere of the country. For example, Chotonagpuri sheep breed of India is found in Meherpur and Chapainawabganj district and its adjacent regions of Bangladesh. Moreover, Garoleis, one of the promising sheep breed in West Bengal of India is also found in Sundarban area in the southern part of Bangladesh (Sharma et al., 1999; Islam and Shahjalal, 2001; Khan et al., 2009).
Indigenous sheep of Bangladesh was crossed in limited scale with (i) three heads of Lohi rams from Pakistan in December 1964, (ii) three Lohi rams and six ewes from Pakistan in December 1969 and (iii) three Romney Marsh and three Parendale rams from New Zealand in 1972. These importations were made by the Bangladesh Agricultural University (BAU), Mymensingh and used in the surrounding areas of BAU. Moreover, the Department of Livestock Services (DLS)was received four Suffolk rams of United Kingdom in 1984 (Hassan and Talukder, 2011). They used these rams to cross coastal sheep at the sheep breeding farm of Sonagazi, Feni district. This farm provided crossbred rams to the local farmers for breeding their sheep. However, these scattered and discontinued attempts could not exert any detectable effect in the sheep industry of the country. Phenotypic characteristics of sheep population of Bangladesh were described

*Corresponding author: debgk2003@yahoo.com 


\section{Genetic relationship among indigenous sheep}

intensively by research (Hassan and Talukder, 2011; Pervage et al., 2009). However, information on genetic characterization of Bangladeshi sheep populations is scare (Tsunoda et al., 1984; Khan et al., 2009) used isozymes method for characterization of Bangladeshi sheep. Khan et al. (2009) first time characterized sheep of different regions of Bangladesh using microsatellite marker without considering breed/type. Considering these facts, this experiment was designed to evaluate genetic relationship among different sheep population of Bangladesh using microsatellite markers.

\section{Materials and Methods}

Based on geographic distribution, management system and breeding history, a total of 96 blood samples were collected from five sheep population of Bangladesh. The populations were Barind (Naogaon, Rajshahi and Chapainowabganj district), Jamuna River Basin (Tangail, Sirajgonj and Mymensingh district), Coastal (Noakhali district), Chotonagpuri (Meherpur district) and Garole (Khulna district) breeds. Samples were collected only from adult sheep of subsistent farmers and BLRI flock. Samples were collected avoiding related animals. Blood was collected in venoject tube, treated with anticoagulant and carried to Molecular Genetics Laboratory of BLRI and preserved at $-20^{\circ} \mathrm{C}$ until DNA extraction. DNA was extracted using a commercial kit (QIAGEN DNA Mini Kit) following manufacturer's instructions.DNA samples were quantified using Nanodrop 2000 spectrophotometer. Thirteen FAO recommended microsatellite primer pairs (Table 1) were used (FAO, 2011). Most of primers used were independent and belonged to different chromosomes. All microsatellite markers were forwardly labeled with a capillary based dye: FAM (blue), PET (Red), VIC (Green) and NED (yellow) for the purpose of genotyping. Sequences, size range and locations of studied primers were showed in Table 1.

Table 1. Microsatellite markers, their sequences, size range and their locations

\begin{tabular}{|c|c|c|c|c|}
\hline $\begin{array}{c}\text { Primer } \\
\text { Name }\end{array}$ & Chromosome & Primer sequences & $\begin{array}{c}\text { Annealing } \\
\text { temperature }\end{array}$ & $\begin{array}{l}\text { Allele } \\
\text { range }\end{array}$ \\
\hline \multirow[t]{2}{*}{ BM8125 } & 17 & F: CTCTATCTGTGGAAAAGGTGGG & 50 & $110-130$ \\
\hline & & R: GGGGGTTAGACTTCAACATACG & & \\
\hline \multirow[t]{2}{*}{ BM757 } & 9 & F:TGGAAACAATGTAAACCTGGG & 58 & $101-172$ \\
\hline & & R: TTGAGCCACCAAGGAACC & & \\
\hline \multirow[t]{2}{*}{ BM1329 } & 6 & F:TTGTTTAGGCAAGTCCAAAGTC & 50 & $160-182$ \\
\hline & & R: AACACCGCAGCTTCATCC & & \\
\hline \multirow[t]{2}{*}{$\mathrm{OMHC1}$} & 20 & F: ATC TGG TGG GCT ACA GTC CAT G & 60 & $189-213$ \\
\hline & & R: GCAATGCTTTCTAAATTCTGAGGAA & & \\
\hline \multirow[t]{2}{*}{ OarFCB128 } & 2 & F:ATTAAAGCATCTTCTCTTTATTTCCTCGC & 55 & $96-130$ \\
\hline & & R:CAGCTGAGCAACTAAGACATACATGCG & & \\
\hline \multirow[t]{2}{*}{ OarFCB20 } & 2 & F: AAATGTGTITAAGATTCCATACAGTG & 56 & $95-120$ \\
\hline & & R: GGAAAACCCCCATATATACCTATAC & & \\
\hline \multirow[t]{2}{*}{ OarFCB304 } & 19 & F:CCCTAGGAGCTTTCAATAAAGAATCGG & 56 & $150-188$ \\
\hline & & R:CGCTGCTGTCAACTGGGTCAGGG & & \\
\hline \multirow[t]{2}{*}{ OraVH72 } & 25 & F:GGCCTCTCAAGGGGCAAGAGCAGG & 57 & $121-145$ \\
\hline & & R:CTCTAGAGGATCTGGAATGCAAAGCTC & & \\
\hline \multirow[t]{2}{*}{ HUJ616 } & 13 & F: TTC AAA CTA CAC ATT GAC AGG G & 54 & $114-160$ \\
\hline & & R: GGA CCT TTG GCA ATG GAA GG & & \\
\hline \multirow[t]{2}{*}{ ILSTS11 } & 9 & F:GCTTGCTACATGGAAAGTGC & 55 & $256-294$ \\
\hline & & R:CTAAAATGCAGAGCCCTACC & & \\
\hline \multirow[t]{2}{*}{ ILSTS5 } & 7 & F: GGAAGCAATGAAATCTATAGCC & 55 & $174-218$ \\
\hline & & R: TGTTCTGTGAGTTTGTAAGC & & \\
\hline \multirow[t]{2}{*}{ MCM140 } & 6 & F: GTTCGTACTTCTGGGTACTGGTCTC & 60 & $167-193$ \\
\hline & & R: GTCCATGGATTTGCAGAGTCAG & & \\
\hline \multirow[t]{2}{*}{ MAF70 } & 14 & F: CACGGAGTCACAAAGAGTCAGACC & 60 & $124-166$ \\
\hline & & R: GCAGGACTCTACGGGGCCTTTGC & & \\
\hline
\end{tabular}

F: Forward primer; R: Reverse primer 
PCR amplifications were performed with a programmable thermal cycler (Bio-Rad, DNA Engine, T100) in a final reaction volume of $25 \mu \mathrm{L}$ using PCR reagents from Invitrogen. Two types of PCR reaction mixture were used. The first reaction system consisted of $2 \mu \mathrm{L}$ of $50 \mathrm{ng}$ of genomic DNA, $0.5 \mu \mathrm{L}$ of each primer, $2.5 \mu \mathrm{L} 10 \mathrm{X}$ PCR buffer, $2 \mu \mathrm{L}$ dNTPs, and $0.937 \cup$ Taq DNA polymerase [TaKaRa Biotechnology (Dalian) China] and the second one consisted of $2 \mu \mathrm{l}$ containing $50 \mathrm{ng}$ genomic DNA, $1 \mu \mathrm{l}$ of each

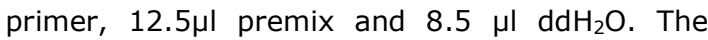
amplification conditions were as follows: $5 \mathrm{~min}$ at $94^{\circ} \mathrm{C}$ for initial denaturing followed by 35 cycles at $94^{\circ} \mathrm{C}$ for $30 \mathrm{~s}$; annealing for $30 \mathrm{~s}$ (Table 1); extension at $72^{\circ} \mathrm{C}$ for $30 \mathrm{~s}$ and a final extension at $72^{\circ} \mathrm{C}$ for $7 \mathrm{~min}$ for all primers. Amplification was confirmed by gel electrophoresis of the PCR products on $2 \%$ agarose gel followed by visualization under UV (Figure 1).

PCR products with different florescent dye were subjected to capillary electrophoresis using GeneScan -500 LIZ Size Standard with DNA Analyzer 3730 of Applied Biosystemin Life Biotech Ltd. China. The exact allele sizes in each primer were determined by GeneMaker V1.85 demo

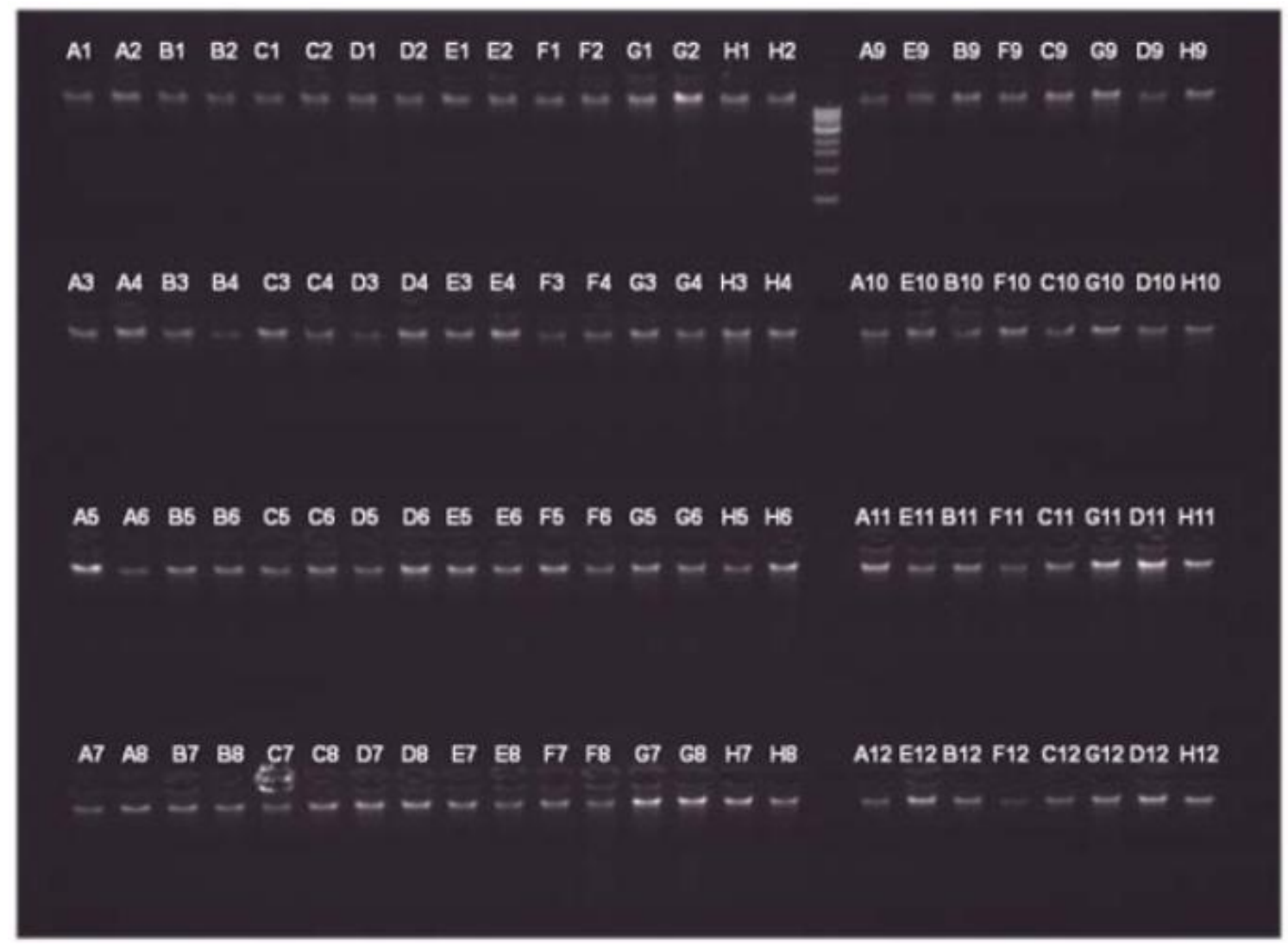

Figure 1. Representative photograph showing PCR products with microsatellite markers

Genotypes were assigned for each animal based on allele size data. Allele frequency, the mean number of alleles per locus, observed heterozygosity, and heterozygosity expected from Hardy-Weinberg assumptions for each locus, and Nei's $D_{A}$ genetic distances (Nei, 1983) were computed using the Microsatellite tool kit and Dispan software package. The Dispan Computer program was used to calculate inter-individual genetic distances, based on the proportion of shared alleles. These distance values were used to construct an unweighted pair group-method 


\section{Genetic relationship among indigenous sheep}

with arithmetic mean (UPGMA) phylogenetic tree using Dispan software (Saitou and Nei, 1987)

\section{Results and Discussion}

Results showed that the number of polymorphic alleles per locus varied from 4in HUJ616 to 12 in MAF70 (Table 2). The mean number of allele and corresponding heterozygosity in each population were shown in Table 3. Highest number of alleles was found in the Barind sheep followed by Jamuna river basin, Chotonagpuri, Garole and
Coastal sheep populations. Khan et al. (2009) also found higher number of alleles in the Barind sheep over the Jamuna river basin. Observed heterozygosity in Jamuna river basin, Barind, Garole, Chotonagpuriand Costal sheep were $0.57 \pm 0.03, \quad 0.63 \pm 0.03, \quad 0.55 \pm 0.04$, $0.58 \pm 0.04$ and $0.54 \pm 0.04$ respectively. Similar pattern were also found in expected heterozygosity, lowest heterozygosity observed in Garole $(0.59 \pm 0.06)$ and highest in Barind sheep $(0.66 \pm 0.04)$.

Table 2. Allele number and sizes of different microsatellites markers

\begin{tabular}{lcl}
\hline Markers & Allele number & \multicolumn{1}{c}{ Allele size } \\
\hline MCM140 & 5 & $169,171,177,179,183$ \\
BM8125 & 5 & $121,125,127,129,131$ \\
OMHC1 & 5 & $315,317,325,327,329$ \\
OraVH72 & 7 & $137,143,145,147,149,153,155$ \\
HUJ616 & 4 & $137,139,141,143$ \\
BM757 & 5 & $196,198,199,201,216$ \\
OarFCB12 & $98,110,112,116,120,122,130$ \\
ILSTS5 & 7 & $189,193,195,197,201,209$ \\
BM1329 & 6 & $158,160,162,174,176,178$ \\
ILSTS11 & 6 & $266,270,272,276,282,284,292,294$ \\
OarFCB20 & 8 & $87,89,91,93,97,99,101$ \\
OarFCB304 & 7 & $149,159,161,163,165,167,169,171,173,177,183$ \\
MAF70 & 11 & $134,136,138,140,142,144,148,150,152,154,156,162$ \\
\hline
\end{tabular}

Table 3. Mean number of alleles and heterozygosity in different sheep populations

\begin{tabular}{lcccc}
\hline Population & $\begin{array}{c}\text { No. of } \\
\text { loci }\end{array}$ & $\begin{array}{c}\text { Mean no. of } \\
\text { alleles }\end{array}$ & $\begin{array}{c}\text { Expected } \\
\text { heterozygosity }\end{array}$ & Observed heterozygosity \\
\hline Jamuna & 13 & $5.00 \pm 1.78$ & $0.62 \pm 0.05$ & $0.57 \pm 0.02$ \\
Barind & 13 & $5.77 \pm 2.45$ & $0.66 \pm 0.04$ & $0.63 \pm 0.03$ \\
Garole & 13 & $4.54 \pm 1.90$ & $0.59 \pm 0.06$ & $0.55 \pm 0.04$ \\
Chotonagpuri & 13 & $4.69 \pm 1.80$ & $0.64 \pm 0.06$ & $0.58 \pm 0.04$ \\
Coastal & 13 & $4.31 \pm 1.89$ & $0.61 \pm 0.06$ & $0.54 \pm 0.04$ \\
Total average & 13 & $4.86 \pm 0.57$ & $0.62 \pm 0.03$ & $0.57 \pm 0.04$ \\
\hline
\end{tabular}

The $D_{A}$ genetic distances between Jamuna river basin, Barind, Garole, Chotonaguri and Costal sheep were expressed in Table 4. Genetic distance between Jamuna river basin and Barind was lowest (0.0891) and between Garole and Costal was highest (0.1786). Garole and
Chotonagpuri sheep has higher genetic distance from other three sheep populations.

Garole is a distinct small sized sheep breed found in the Sundarban area in the southern part of Bangladesh and West Bengal of India (Sharma et al.,1999; Islam and Shahjalal, 2001; Khan et al., 
Deb et al. (2019) Bang. J. Anim. Sci. 2019. 48 (1):17-22

2009). Garolewas identified as a distinct sheep breed (Mukesh et al., 2006; Khan et al., 2009). This study further identified genetic identity of the Garole from indigenous sheep populations of Bangladesh. Chotonagpuri is an Indian sheep breed is entering into Bangladesh through illegal trading in the border areas. Sheep of this breed are found in the Meherpur district and its adjacent areas. Chotonagpuri sheep was included in this study as a reference breed. The present study identified it as a separate genetic group from the Indigenous sheep of Bangladesh.

Table 4. $D_{A}$ genetic distances among five different sheep populations

\begin{tabular}{lccccc}
\hline & Jamuna & Barind & Garole & Nagpuri & Coastal \\
\hline Jamuna & 0.000 & & & & \\
Barind & 0.0891 & 0.000 & & & \\
Garole & 0.1451 & 0.1651 & 0.000 & & \\
Nagpuri & 0.1479 & 0.1551 & 0.1773 & 0.000 & 0.000 \\
Coastal & 0.1162 & 0.1336 & 0.1786 & 0.1706 & \\
\hline
\end{tabular}

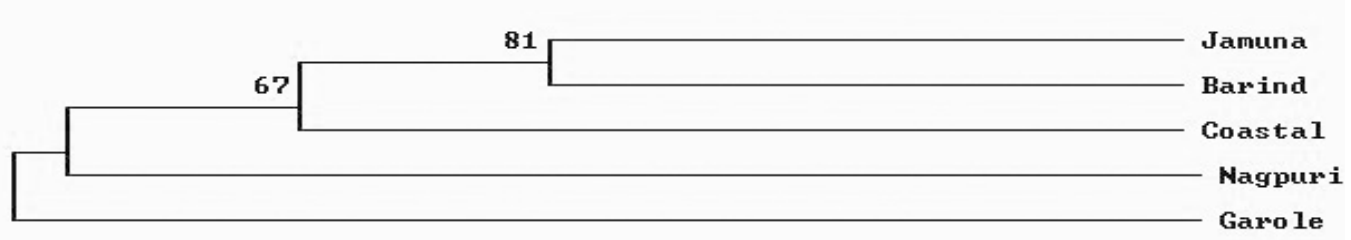

Figure 2. Dendrogram showing genetic relationship among five sheep populations

The low genetic distances between Barind and Jamuna river basin sheep populations indicates their common genetic background. Khan et al. (2009) also reported that the sheep of the central and northern Bangladesh are belonging to similar genetic group. In their study, sheep of Jamuna river basin was included in the central and sheep of Barind group was included into Northern group.

Dendrogram based on $D_{A}$ genetic distance using un-weighted pair group method of arithmetic means (UPGMA) indicated segregation of the five (5) populations of sheep into four main clusters (Figure 2). Cluster 1 consisted of Barind and Jamuna river basin sheep. Garole and Nagpuri sheep have fallen into two separate clusters (cluster-3 and cluster-4). Cluster of Coastal sheep (cluster-2) is closer to Barind and Jamuna river basin sheep than Garole and Nagpuri sheep also justified the integration of indigenous sheep genetic resources. Garole sheep was unique because of its minimum number of allele and lower heterozygosity and higher genetic distance from other sheep populations. Our results on this genetic group also supported by the previous cultural and historical evidences (Khan et al., 2009) Coastal sheep are also a distinct genetic group in the dendrogram. Coastal sheep might possess the remnant genetic materials from Australian Suffolk breed introduced in that breeding area during 1980 and also contributed in genetic partitioning.

\section{Conclusion}

Considering findings of the present study on average allele numbers, heterozygosity and standard genetic distances and dendrogram, it may be concluded that the Barind and Jamuna river basin sheep are belonging to a similar genetic group while, Garole and Coastal sheep are two distinct genetic groups.

\section{References}

FAO (Food and Agricultural Organization) (2011). Molecular genetic characterization of animal genetic resources, FAO Animal Production and Health Guidelines.

Hassan MR, Talukder MAI (2011). Comparative performance of different regional native sheep in Bangladesh. The Bangladesh Veterinarian, 28(2): 85 -94.

Islam ABMM, Shahjalal M (2001). Ruminant production and research. Agricultural research in Bangladesh in the 20th Century. Wadud Mian MA. BARC /BAAG. P.419-421. 


\section{Genetic relationship among indigenous sheep}

Khan MYA, Han J, Husain SS, Alam MR, Teneva A, Faruque MO (2009). Genetic relationship in different sheep population of Bangladesh based on microsatellite markers. Journal of Bangladesh Agricultural University, 7: 291-294.

Mukesh M, Sodhi M, Bhatia S (2006). Microsatellite based diversity analysis and genetic relationships of three Indian sheep breeds. Journal of Animal Breeding and Genetics, 123: 258-264.

Nei M, Tajima F and Tateno Y (1983). Accuracy of estimated phylogenetic trees from molecular data. Journal of Molecular Evolution, 19: 153170.

Pervage S, Ershaduzzaman M, Talukder MAI, Hasan MN, Khandoker MAMY (2009). Phenotypic characteristics of indigenous sheep of Bangladesh. Bangladesh Journal of Animal Science, 38(1\&2): $1-6$
Saitou N, Nei (1987). The neighbor-joining method: A new method for reconstructing phylogenetic tree. Molecular Biology and Evolution. 4:406425.

Sharma, RC, Arora, AL, Narula, HK,Singh, RN (1999).Characteristics of garole sheep in India. Animal Genetic Resource Information Bulletin, 26: $57-64$

Siddiky NA (2018). Animal breeding policies and strategies in South Asia, SAARC Agriculture Centre (SAC), BARC Complex, New Airport Road, Farmgate, Dhaka. P 7.

Tsunoda K, Amano T, Katsumata M, Nozawa K, Namikawa T, Tsubota $Y$, Hasnath MA, Mostafa KG and Faruque MO (1984). Morphological characters and blood protein polymorphisms in the sheep of Bangladesh. Genetics studies on breed differentiation of native domestic animals in Bangladesh. Tokyo University of Agriculture. P. 57-85. 